\title{
Perception and production of Italian L2 sounds
}

Luciano Romito, Manuela Frontera

Department of Languages and Education, University of Calabria, Italia

https://doi.org/10.36505/ExLing-2015/06/0018/000255

\begin{abstract}
Various theories and models have been argued in order to explain the phonological and phonetic influence or interference of native language on perception and interpretation of L2 categories (Vayra et al. 2012, Kuhl et al. 2006), and whether or how much production depends on it (Bohn \& Flege 1990). The oppositions examined here deal with vowels (final unstressed /e-i/, /o-u/, an opposition that in Galician language is reduced to $/ \mathrm{e}-\mathrm{O} /)$ and consonants $(/ \mathrm{b}-\mathrm{v} /, / \mathrm{ts}-\mathrm{dz} /$, both absent in Galician). The goals are: (a) to verify levels of identification of Italian non-native vowel and consonant oppositions by Galician students of Italian L2; (b) to analyse discrepancies in production between Italian native speakers and Italian L2 learners.
\end{abstract}

Key words: applied linguistics, L2 learning, phonetic perception, production, PAM

\section{Identification experiments \\ Method \\ Participants}

Twenty-four undergraduate students of the University of Santiago de Compostela (Galicia, Spain), without history of severe language or hearing impairments, participated in this study. They were all students of Italian L2, twelve since one/two year/s, twelve since three/four. All students were Galician but some of them use Castellan as L1.

\section{Stimuli and procedures}

Two identification tests were proposed to the students using Folerpa (Fernández Rei et al. 2014). Stimuli were recorded by three native Italian speakers (2F, $1 \mathrm{M}$ from northern and central Italian varieties). They consisted of words pronounced in the phrasal context "dico X rapidamente/con calma" ("I say X rapidly/with calm") where $X$ is the target word. Both real and nonsense words were used. The target words were then isolated and normalized by an editing software. Each test consisted of 180 tokens ( 9 minimal pairs, 4 oppositions, 5 repetitions per word) divided into four blocks. The first test dealt with vowel oppositions of final unstressed /e $-\mathrm{i} /, / \mathrm{o}-\mathrm{u} /$, the second with consonants $/ \mathrm{b}-\mathrm{v} /, \mathrm{ts}-\mathrm{d} /$. Every token was repeated twice after $1 \mathrm{sec}$. interval and presented with no feedback. Time responses were also evaluated. Results to the tests were compared with those of a control group of six native Italians from the University of Calabria.

ExLing 2015: Proceedings of 6th Tutorial and Research Workshop on Experimental Linguistics, 26-27 June 2015, Athens, Greece 


\section{Results and discussions \\ Vowels}

The relations between correct identifications and years of Italian L2 experience or first language of subjects (Galician/Castellan) were not significant according to chi-square tests $(=0,036 ; 0,0001)$ and one-way ANOVA results. Subjects successfully identified final unstressed /e/ and /o/ (native oppositions), better than $/ \mathrm{i} /$ and $/ \mathrm{u} /$ (non-native oppositions), as well as the control group did: this could reasonably depend on an intrinsic poor quality realization of unstressed final vowels by the Italian speakers (Romito et al. 1997). Time responses means confirm the tendency to a lower identification of high vowels.

\section{Consonants}

Statistical analysis reveal slightly significant differences between Galician and Castellan L1 speakers: the lasts seem to identify better all consonant oppositions, even if both groups obtain percentages of success worse than the previous test $(79-98 \%$ to $57-90 \%)$. Percentages decrease when associated to non-native sounds $/ \mathrm{v} / \mathrm{,} / \mathrm{ts} /$ and $/ \mathrm{d} /$, where the affricate $/$ ts / gets the worst results, while the native sound $/ \mathrm{b} /$ is almost often correctly identified. Time responses show troubles in the identification of voiced/unvoiced affricates, as well as for the Italian control group: this may confirm an unaware distinction in the use of the two phonemes by Italian speakers, due to the unpredictability of this specific opposition (Gili Fivela 2010).

\section{Production \\ Method \\ Participants}

Seven female Italian L2 students of the University of Santiago de Compostela and two Italian native speakers. All students were Galician and use Galician as a first language. Native speakers productions were the same used for perceptual experiments.

\section{Corpus}

All speakers produced 30 phrases per vowel opposition, containing 15 minimal pairs of target words (ex. 'Dico molti rapidamente, dico molte rapidamente'; 'dico pirco con calma, dico pircu con calma'). Target words were isolated by an editing software. Final unstressed vowels were labeled and analysed by Praat (5.4.09). Values of $F_{1}, F_{2}$ and duration were extracted by means of a script adapted by Luciano Romito.

\section{Results and discussions}

Italian L1 productions of final unstressed vowels reflect processes of intrinsic centralization in front vowels areas and neutralization in back ones: 


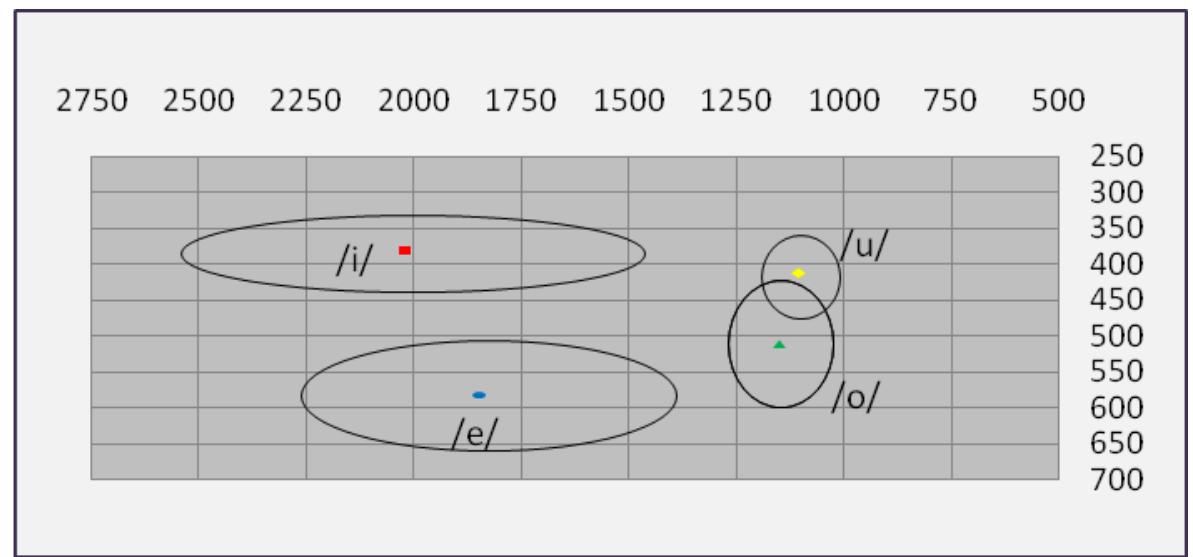

Figure 1: Italian unstressed vowels areas. $F_{2}$ values are on the $x$-axis, $F_{1}$ values are on the ordinate.

Galician speakers 'polarize' front vowels /i - e/ and back /u/, while close-mid /o/ is almost centralized: these results show both likely efforts in producing the opposition between close and close-mid front vowels, and a strong influence of Galician L1 close-mid vowels production, almost evident in /o/, extremely centralized (Regueira 2003). Extra-fronted realization of /i/ and /e/ reflects longer durations of Italian L2 vowels respect to the Italian L1 ones. On the contrary, Italian L2 back vowels duration is slightly reduced.

Table 1: Values of $F_{1}, F_{2}$ and duration of Italian L1 and L2 final unstressed vowels produced by female subjects.

\begin{tabular}{|c|c|c|c||c|c|c|c|}
\hline \hline \multicolumn{3}{|c||}{ Ita_L1 } & \multicolumn{4}{c|}{ Ita_L2 } \\
\hline & F1 & F2 & (ms.) & & F1 & F2 & (ms.) \\
\hline [e] & 586 & 1927 & 61.783 & {$[\mathbf{e}]$} & 538 & 2074 & 69.882 \\
\hline$[\mathbf{i}]$ & 389 & 2003 & 62.402 & {$[\mathbf{i}]$} & 404 & 2425 & 75.166 \\
\hline [o] & 511 & 1147 & 52.729 & {$[\mathbf{o}]$} & 459 & 1045 & 45.268 \\
\hline$[\mathbf{u}]$ & 422 & 1072 & 46.157 & {$[\mathbf{u}]$} & 415 & 828 & 43.735 \\
\hline \hline
\end{tabular}




\section{Conclusion}

The perception of sounds belonging to an L2 is partly influenced by the phonetic and phonological features of the native language. This study reveals how the perception of native sounds is almost always correct compared to that of nonnative ones. However, the proximity of the two linguistic systems usually guarantees high percentage scores of success. As far as production is concerned, the current work is at the moment focused on vowels, but it will soon include an analysis on the consonant oppositions perceptually tested. By now, the production of nonnative vowel oppositions seems to confirm an ability in discrimination, tested by the perceptual experiments, although it appears rather unnatural. In this sense, it is possible to confirm that L1 not only affects perception but also production in L2: as a consequence, learners will be able to produce L2 oppositions, but with acoustic values almost near to the equivalent native sounds. Further analysis on the connection existing between perception and production will be led on consonants, which seemed to be more problematic for our subjects.

\section{References}

Bohn, O.-S., Flege, J. 1990, Interlingual identification and the role of foreign language experience in L2 vowel perception in Applied Psycholinguistics, 11, 303-328.

Fernández Rei, E. (coord.), 2014, FOLERPA: Ferramenta On-Line para ExpeRimentación PerceptivA. Santiago de Compostela: Instituto da Lingua Galega. http://ilg.usc.es/FOLERPA/

Gili Fivela, B. 2010, Affricate, in Enciclopedia dell'Italiano, R. Simone (dir.), Istituto della Enciclopedia Italiana G. Treccani, Roma.

Regueira, X. L. 2003, Vocais finais en galego e en portugués: un estudio acústico, Actas do VII Congreso Internacional de Estudios Galegos (Barcelona, 28-31 de maio de 2003).

Romito L., Turano T., Loporcaro M., Mendicino A. 1997, Micro e Macrofenomeni di centralizzazione nella variazione diafasica: rilevanza dei dati fonetico-acustici per il quadro dialettologico del calabrese in Atti del convegno VII Giornate di Studio del Gruppo di Fonetica Sperimentale (Napoli, novembre 1996).

Tsao, F. M., Liu, H. M., Kuhl, P.K. 2006, Perception of native and non-native affricatefricative contrasts: Cross-language tests on adults and infants, The Journal of the Acoustical Society of America 120 (4), 2285-2294.

Vayra, M., Avesani, C., Best, C. T., Bohn, O. S. 2012, Non solo dettagli fonetici, non solo categorie fonologiche: l'interazione tra fonetica e fonologia nella percezione di suoni non-nativi, in Studi e Saggi Linguistici, Pisa, ETS. 